\title{
Migration and Mental Health: Sociodemographic and Clinical Characteristics of a Sample of Nigerians Who Had Mental Breakdown during their Sojourn Overseas
}

\section{Obayi NOK*}

Department of Psychiatry, Federal Teaching Hospital, Nigeria

*Corresponding author: N Okwudili K Obayi, Department of Psychiatry, Ebonyi State University, Abakaliki \& Dept of Psychiatry, Federal Teaching Hospital, Abakaliki, Nigeria, Tel: +2348037784345; Email: nokobayi@gmail.com

\section{Research Article}

Volume 3 Issue 4

Received Date: May 14, 2018

Published Date: May 28, 2018

\section{Abstract}

Since time immemorial, human beings have moved from one place to another and the process of migration and its accompanying stressors affect migrating individuals and their families. This process is neither simple nor straightforward and at times impacts negatively on the migrant leading to mental health challenges and impairing the achievement of the purpose of travelling. This study aimed at determining the sociodemographic and clinical characteristics of a sample of Nigerians who travelled outside the country but developed (or relapsed from) mental disorders and on return sought for medical attention in our facility.

Relevant sociodemographic and clinical data were extracted using a researcher-developed questionnaire and analysis done using the SPSS, version 22. Fifty-two eligible and consenting patients (48\% males, 52\% females), aged 15 - 36 years (mean= 24.3 \pm 10.5 years), were recruited over the 4-year study period. Major purpose of travel was to study, trade or do menial jobs though up to one-quarter had nothing in particular in mind to do on arrival to their destination. Europe and Asia were the continents that majority travelled to. $25 \%$ were incarcerated in foreign countries while migrating and about $77 \%$ were compelled to return home. $79 \%$ had mental breakdown within the first two years of leaving Nigeria. It was the first time that majority (82.7\%) travelled out of Nigeria. Schizophrenia was the most diagnosed condition while finance, academic, accommodation, and psychoactive substance use-related issues were the most reported or suspected stressors. Proper psychiatric evaluation is advocated for young people who wish to travel out, especially vulnerable individuals. Parents are also advised not to enforce a career on their children and the current efforts of the Nigerian government to regulate exit from the country should be supported while government is also urged to address the key factors that warrant youths from leaving the country.

Keywords: Migration; Mental Disorders; Sociodemographic and clinical characteristics 


\section{Psychology \& Psychological Research International Journal}

\section{Introduction}

Migration is a process of social change in which an individual, alone or in company of others, because of one or more reasons of economic betterment, political upheaval, education or other purposes, leaves one geographical area for a prolonged stay or permanent settlement in another geographical area [1]. The process involves an initial experience of a sense of loss, dislocation, alienation and isolation besides the social network that is left behind [1].

The economic, political and social changes which have occurred globally in recent years have influenced international migration in some countries [2]. People migrate from their own countries, mainly from rural to urban areas, as well as across borders. The main reason for choosing to be a migrant is to seek a better life via finding a better job, better security of human life, as well as work opportunities. For these reasons, coupled with terrorism and incessant killings by known and unknown persons in some countries, the number of immigrants is constantly increasing year on year. Hence, immigration has become a significant research topic in recent years and a global issue for all countries.

A key outcome of successful immigrant settlement and integration is good mental and physical health, defined simply as feeling good and functioning well in daily life activities and contributing positively to one's community [3]. As one moves, he or she is faced with many factors in the new environment. These factors, combined with the level of stress and the person's overall ability to cope with such factors and stress, will produce either a sense of settling down or a sense of feeling isolated and alienated. The purpose for which migration was undertaken, premigratory preparation processes, and social support, all enhance an individual's coping mechanisms. In addition, the way the emigrant is accepted and welcome by the new nation will also significantly influence the genesis of stress and how the individual deals with such stress.

Nigerians, like many from some other developing countries, have records of frequent migration to other countries for better life. Of recent, one major reason for Nigerian youths travelling abroad has been to study overseas, not necessarily because of better quality of education but because of the relative ease to gain admission into some of the foreign universities or courses they could not be offered by Nigerian universities. Another reason is the incessant industrial actions of workers in Nigerian tertiary institutions over the years which continually interrupt the academic programmes of the students. Gaining admission into these oversea institutions involves a lot of money and other stressful experiences and a good number of these Nigerian youths who leave the country with the hope of coming back with higher academic degrees or business achievements end up breaking down mentally, often within few months to years of travelling outside Nigeria.

There is a complex relationship between migration and its processes and the impact on individuals and their subsequent development of psychological or psychiatric conditions [1]. Various scholars have reported the development of mental disorders among migrants $[4,5]$. Schizophrenia is one of the commonest mental disorders reported among migrants and various hypotheses have been postulated to explain the increased rates of mental disorders (especially schizophrenia) among migrants $[1,6]$.

Factors that contribute to mental health challenges among Nigerian emigrants include: employment challenges in the new country, fear of failure, pressure from highly expectant family members at home, language difficulties, finances, academic challenges, accommodation or settlement challenges (often worsened by non-possession of valid residential documents), initiation into (or increased) use of illicit or psychoactive substances, and others.

The consequence of these challenges is the predisposition to or precipitation of mental illness in a vulnerable migrant. Incidentally, the families of many of these victims may never know what their wards are passing through overseas and even when they do, they would find it difficult to offer immediate help because of the distance. Many of those who broke down mentally had overt abnormal manifestations over there while some manifested clearly on return to Nigeria, especially those who were duped (for instance, via fake visa provision after paying so much money) and managed to return or be deported thereafter.

Many local and international scholars have studied the impact of migration on mental health but hardly did any of these studies report on the characteristics of the migrants who developed mental illnesses during their trips (as a prelude to a later comparative study with other migrants who did not develop any mental disorder though exposed to similar conditions). 


\section{Psychology \& Psychological Research International Journal}

\section{Objective of the Study}

The objective of this study was to determine the sociodemographic and clinical characteristics of Nigerians who travelled outside the country for better life but developed mental disorders necessitating their voluntary or forceful return without actualizing the purpose of their emigration.

\section{Methods}

This prospective study involved the recruitment of consecutive consenting eligible patients who presented to our facility for treatment over a 4-year period (1st January, 2014 to 31st December, 2017). To be eligible, the individual must: qualify for a psychiatric diagnosis at the time of presentation; have travelled outside the country for a period of at least six months; not have met any psychiatric diagnosis before he travelled outside Nigeria or where he had, must have been stable for at least 12 months before he travelled out; and he or she must have developed mental illness for the first time (or relapsed) while outside the country.

A researcher-developed instrument that captured the demographics, clinical picture, and travel details of the individuals was used to extract information from participants. Thereafter, the data were analyzed using the statistical package for social sciences (SPSS), version 22. All variables were summarized using standard descriptive statistics such as frequencies.

\section{Results}

\section{Sociodemographic Characteristics}

A total of 57 eligible patients were enrolled within the 4 -year study period but 5 were disqualified eventually because of contradictions in the information provided by the patients and their family members.

Table 1 shows the distribution of the participants according to sex, age, marital status, educational attainment, and employment status prior to migration. $48.1 \%$ of the participants were males, $51.9 \%$ females. They were aged 15 - 36 years; mean age being $24.3 \pm 10.5$ years with the majority falling in the age range of $18-25$ years. Forty-nine $(94.2 \%)$ were Igbos and only three (5.8\%) were married at the time of travelling. Each of the participants had some level of formal education before travelling, with as much as $82.7 \%$ having completed at least their secondary education. One-third (34.6\%) had no occupation as at the time of travelling while only 3 (5.8\%) had full time job and another one-third (32.7\%) were into full time study.

\begin{tabular}{|c|c|c|}
\hline \multirow{2}{*}{ Demographic variable } & \multicolumn{2}{|c|}{ Frequency } \\
\hline & Number (n) & Percentage (\%) \\
\hline Gender & & \\
\hline Male & 25 & 48.1 \\
\hline Female & 27 & 51.9 \\
\hline Age (years) & & \\
\hline$<18$ & 3 & \\
\hline $18-25$ & 28 & 5.8 \\
\hline $26-30$ & 12 & 53.8 \\
\hline $31-35$ & 6 & 23.1 \\
\hline $36-40$ & 3 & $\begin{array}{c}11.5 \\
5.8\end{array}$ \\
\hline Mean $=24.3 \pm 10.5$ & & \\
\hline Family setting & & \\
\hline Monogamous & 40 & 76.9 \\
\hline Polygamous & 12 & 23.1 \\
\hline Marital status & & \\
\hline Single (never married) & 49 & 94.2 \\
\hline Married & 3 & 5.8 \\
\hline Ethnicity & & \\
\hline Igbo & 49 & 94.2 \\
\hline Non-Igbo & 3 & 5.8 \\
\hline Educational attainment & & \\
\hline Dropped in Primary & 3 & 5.8 \\
\hline Completed Primary & 3 & 5.8 \\
\hline Dropped in Secondary & 3 & 5.8 \\
\hline Completed Secondary & 31 & 59.6 \\
\hline Above Secondary & 12 & 23.1 \\
\hline Employment status & & \\
\hline Nil & 18 & 34.6 \\
\hline Apprenticeship & 2 & 3.8 \\
\hline Trading & 9 & 17.3 \\
\hline Working full time & 3 & 5.8 \\
\hline Housewife & 3 & 5.8 \\
\hline Full time study & 17 & 32.7 \\
\hline
\end{tabular}

Table 1: Distribution of the participants according to sex, age, marital status, ethnicity, educational attainment, and employment status at the time of travelling out, $n=52$.

\section{Travel Details}

Information regarding the travelling details of those studied is presented in table 2,3 . The travel during which the participants had mental challenge was the first time that $43(82.7 \%)$ left the country (Nigeria) and also the first time that $21(40.4 \%)$ left and lived outside their parents or family members. While one-third $(32.7 \%)$ travelled for academic purposes, one-quarter had in mind 


\section{Psychology \& Psychological Research International Journal}

to do some menial or any type of job they see on arrival to their destination. As much as $15 \%$ refused to disclose the intention of their travel.

Of the 17 persons that travelled to study, 12 (70.6\%) went to study Medicine, $2(11.8 \%)$ to study Law, and the rest $(17.6 \%)$ to study other courses like Engineering, Graphic designing, and Masters in Accounting. Majority had the full consent of their families concerning the travel but about $29 \%$ had their families disagree or reluctantly approved the migration. Only 3 (5.8\%) of the participants sponsored the trip themselves.

More than two-thirds (69.2\%) had to pay a huge sum of money to travel agents for visa procession and other services. Out of this, $10(19.2 \%)$ were given either a fake visa or visa permits of periods shorter than those stated in the documents provided to them by the agents. Most of them travelled to Europe and Asia. Only two-third
(65.4\%) had official valid residential permit/cards as at the time of onset of mental breakdown. As much as 22 $(42.3 \%)$ travelled alone while only 6 persons $(11.5 \%)$ travelled with family members. Up to $76.9 \%$ did not travel direct from Nigeria to their final destination they migrated via one or more countries before arriving to the country where they had mental breakdown. On arrival to the country of settlement, only a minority stayed with people previously known to them.

The participants reported facing various problems on arrival to the foreign country, such as: academic (46.2\%), accommodation (34.6), language (34.6\%), securing of jobs (28.8\%), financial difficulties (23.1\%), companionship/loneliness (23.1\%), and residential permit/illegal papers (19.2\%). Up to a quarter (25\%) got incarcerated before returning to Nigeria. Close to half $(46.1 \%)$ were eventually deported back to Nigeria, while $30.8 \%$ were forced or brought back by their families.

\begin{tabular}{|c|c|c|}
\hline Variable & \multicolumn{2}{|c|}{ Frequency } \\
\cline { 2 - 3 } Yes & Number (n) & Percentage (\%) \\
No & 43 & 82.7 \\
First trip outside Nigeria & 9 & 17.3 \\
\hline Yes & & 40.4 \\
No & 21 & 59.6 \\
\hline Purpose of travel & 31 & 25.0 \\
Menial/any available job & & 21.2 \\
Trading & 13 & 32.7 \\
Academic (to study) & 11 & 5.8 \\
Marital (to join spouse) & 17 & 15.4 \\
Others (undisclosed) & 3 & \\
\hline Medicine & 8 & 70.6 \\
Law & & 11.8 \\
Course of study (for those who travelled for academic purpose, n=17) & & 17.6 \\
Others (Engineering, Graphic & 12 & \\
designing, \& MSc Accounting) & 2 & 71.2 \\
Family's agreement to the trip & 3 & 23.1 \\
Fully agreed & & 5.8 \\
Reluctantly agreed & 37 & \\
Fully disagreed & 12 & 30.8 \\
\hline Yes & 3 & \\
No & 36 & \\
\hline Huge sum paid to travel agents for visa \& other services & & \\
\hline
\end{tabular}




\section{Psychology \& Psychological Research International Journal}

\begin{tabular}{|c|c|c|}
\hline Sponsor of the trip & & \\
Patient (participant) & 3 & 5.8 \\
Parent(s) & 36 & 69.2 \\
Sibling/relative/friend & 5 & 9.6 \\
Spouse & 2 & 3.8 \\
Others (government scholarship, & 6 & 11.6 \\
human trafficker) & 19 & 36.5 \\
Place (continent) travelled to & 9 & 17.3 \\
Europe & 15 & 28.8 \\
America/Canada & 9 & 17.3 \\
Asia & 9 Africa & \\
\hline
\end{tabular}

Table 2: Travel details of the participants $(n=52)$

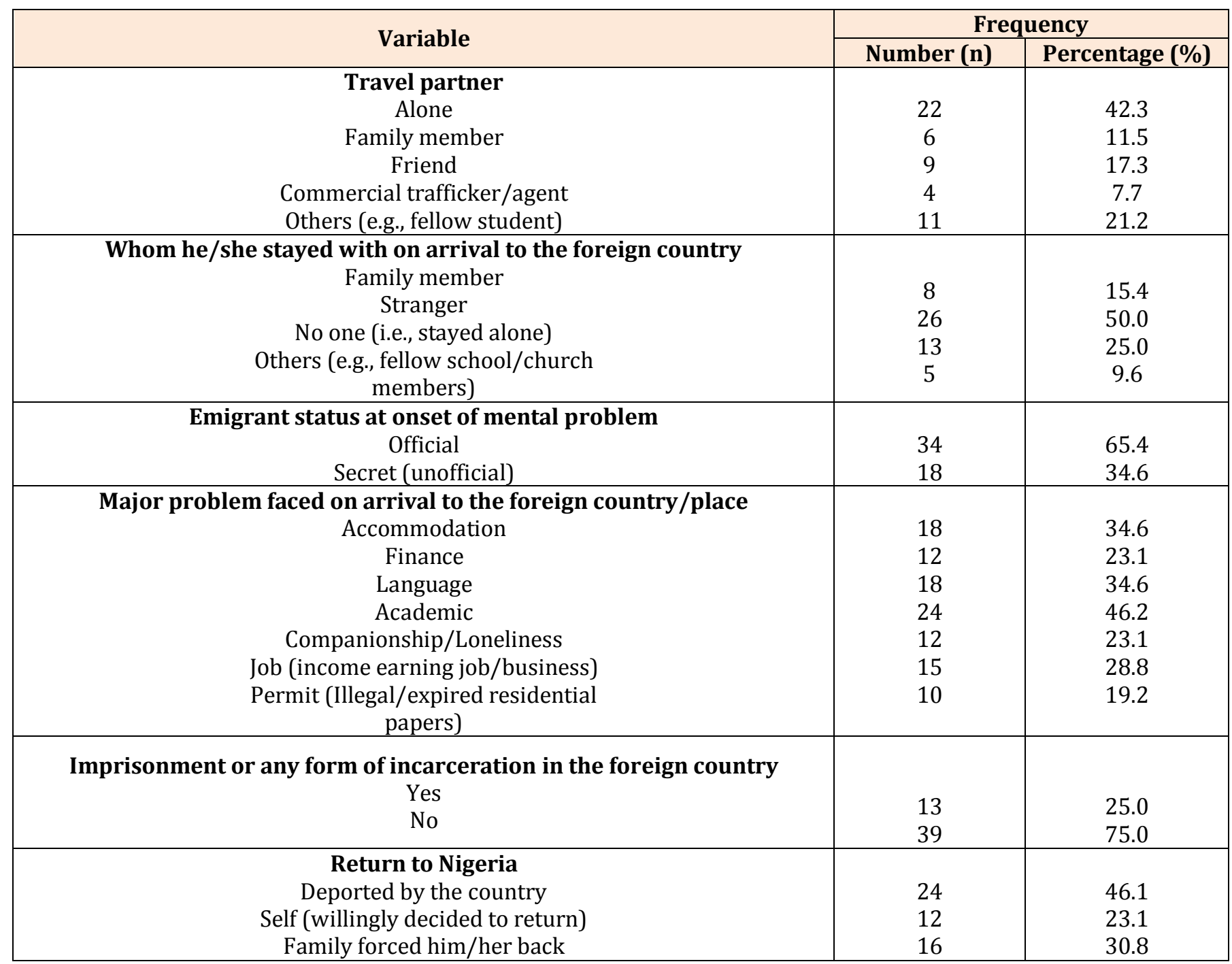

Table 3: (contd) Travel details of the participants $(n=52)$ 


\section{Psychology \& Psychological Research International Journal}

\section{Clinical Characteristics}

Table 4 shows the clinical profile of the participants. Four of the 52 participants $(7.7 \%)$ had experienced one form of psychological disorder or the other prior to travelling out of Nigeria. Only two of these 4 ever received orthodox treatment for the mental disorder before travelling. About a quarter reported having used psychoactive substances prior to travel and only 6 $(11.5 \%)$ admitted a positive family history of mental illness.

Two-third (69.2\%) described the level of stress they experienced as either severe or unbearable. Most of them broke down within the first two years of leaving Nigeria and up to $82.7 \%$ received hospital care in the country where they broke down before returning to Nigeria. Schizophrenia was the topmost diagnosis $(57.7 \%)$ while financial difficulties were the most reported stressor.

\begin{tabular}{|c|c|c|}
\hline \multirow{2}{*}{ Variable } & \multicolumn{2}{|c|}{ Frequency } \\
\hline & Number (n) & Percentage (\%) \\
\hline $\begin{array}{c}\text { History of mental illness before travelling } \\
\text { Yes } \\
\text { No }\end{array}$ & $\begin{array}{c}4 \\
48\end{array}$ & $\begin{array}{c}7.7 \\
92.3\end{array}$ \\
\hline $\begin{array}{l}\text { Received orthodox treatment for mental illness before travelling } \\
\text { Yes } \\
\text { No }\end{array}$ & $\begin{array}{c}2 \\
50\end{array}$ & $\begin{array}{c}3.8 \\
96.2\end{array}$ \\
\hline $\begin{array}{c}\text { (Mis)used psychoactive substance(s) before travelling out } \\
\text { Yes } \\
\text { No }\end{array}$ & $\begin{array}{l}12 \\
40\end{array}$ & $\begin{array}{l}23.1 \\
76.9\end{array}$ \\
\hline $\begin{array}{c}\text { Family history of mental illness } \\
\text { Yes } \\
\text { No/Uncertain }\end{array}$ & $\begin{array}{c}6 \\
46 \\
\end{array}$ & $\begin{array}{l}11.5 \\
88.5\end{array}$ \\
\hline $\begin{array}{l}\text { Description of the level of stress experienced on leaving Nigeria } \\
\text { No stress experienced } \\
\text { Mild } \\
\text { Moderate } \\
\text { Severe/unbearable }\end{array}$ & $\begin{array}{l}2 \\
4 \\
10 \\
36\end{array}$ & $\begin{array}{c}3.8 \\
7.7 \\
19.2 \\
69.2\end{array}$ \\
\hline $\begin{array}{l}\text { Duration of stay outside before the onset mental breakdown } \\
\text { Less than } 6 \text { months } \\
6-24 \text { months } \\
\text { Above } 2 \text { years }\end{array}$ & $\begin{array}{c}3 \\
38 \\
11\end{array}$ & $\begin{array}{c}5.8 \\
73.1 \\
21.2\end{array}$ \\
\hline $\begin{array}{c}\text { Admitted or treated for abnormal behaviour overseas } \\
\text { Yes } \\
\text { No }\end{array}$ & $\begin{array}{c}43 \\
9\end{array}$ & $\begin{array}{l}82.7 \\
17.3\end{array}$ \\
\hline $\begin{array}{c}\text { Clinical diagnosis } \\
\text { Schizophrenia } \\
\text { Mood disorder } \\
\text { Substance use/co-morbid disorder } \\
\text { Adjustment disorder } \\
\text { Delusional disorder } \\
\end{array}$ & $\begin{array}{c}30 \\
11 \\
11 \\
1 \\
1\end{array}$ & $\begin{array}{l}57.7 \\
21.2 \\
21.2 \\
1.9 \\
1.9\end{array}$ \\
\hline $\begin{array}{c}\text { Suspected key stressors } \\
\text { Relapse (poor drug compliance) } \\
\text { Substance use } \\
\text { Accommodation } \\
\text { Financial difficulties } \\
\text { Academic issues/stress } \\
\text { Others* } \\
\end{array}$ & $\begin{array}{l}4 \\
11 \\
12 \\
16 \\
12 \\
8\end{array}$ & $\begin{array}{l}7.7 \\
21.3 \\
23.1 \\
30.8 \\
23.1 \\
15.4\end{array}$ \\
\hline
\end{tabular}

*Others: pregnancy-related, loneliness, racial discrimination, marital, unidentified.

Table 4: Clinical characteristics of the participants, $n=52$. 


\section{Psychology \& Psychological Research International Journal}

\section{Discussion}

Both males and females migrated almost equally, a finding similar to those of many other researchers $[7,8]$. The age range mostly affected ( $18-25$ years) is the age of the onset of most non-affective psychotic disorders like schizophrenia (which was dominant in this population) as well as the age of initiation/active psychoactive substance use [9].

One third had no job prior to travelling out, justifying the report that unemployment is a risk factor to emigration and aligning with some Nigerian studies which reported that one of the key reasons for leaving the country was for initial or better employment or remuneration [10-12].

Majority of the participants had just traveled outside the country for the first time before the mental breakdown. Agarwal and colleagues had reported that there is a high prevalence of psychological distress usually just after migration [13]. Most of those who travelled for academic purposes went to study courses known to be very competitive during university admissions in Nigeria such as Medicine and Law. These are among the courses noted to be popular among Nigerians who migrated to study in the United Kingdom [14].

Many spent a lot of money to enable them travel out of Nigeria. Such expenses were often made to lawenforcement agents or travel agents who assist travelers on visa procurement [15].

Over two-thirds travelled gradually from one country to the other until they got to their final destination. One author has reported that the routes taken by migrants to Europe are highly dynamic, often shifting quickly in response to new restrictions at borders or security concerns in transit countries while taking a lot of risks [16]. Another author (an oversea-based Nigerian scholar) noted that the migration processes is in continuity, implying that the migrants neither have a perceived end nor a beginning; that individuals at different stages in times and space can be part of a different type of the continuity-based migration model, depending on the progress a migrant has made as well as influenced by the social and spatial context of a migrant; and that there can be several back-and-forth movements and return must therefore be understood not as an end of the migration process, since re-emigration can follow [17].
Various problems were encountered by the migrants on arrival to a new country, ranging from accommodation to financial difficulties to possession of illegal papers (resident permits/cards), all serving as risk factors to mental illness, especially in vulnerable individuals. Similar findings have been reported $[18,19]$.

Up to a quarter were arrested and detained for offenses such as possession of fake or expired residential cards or visas and use of illicit drugs, among other minor offences. There have been reports of thousands of Nigerians leaving the country illegally and the country recently took steps to curtail such illegal exits [20,21]. Close to half were forcefully repatriated back to Nigeria [22]. This is a common trend. Recently, Libyan government was reported to have deported up to 252 Nigerian illegal immigrants back to Nigeria.

A greater percentage perceived the stress experienced by them during the travel as severe or unbearable, supporting why they had to breakdown mentally - a finding in keeping with earlier studies [23,24].

Schizophrenia was the most diagnosed disorder in our sample. This is in line with many earlier studies conducted in multiple nations which reported a higher incidence rate of psychosis among immigrants [25,26]. It is also in keeping with earlier report by Bhugra and Jones who also hypothesized that: the countries of origin where the victims migrated from might have high rates of schizophrenia; that people with schizophrenia were predisposed to migrate; and that migration produced stress which could initiate schizophrenia [27].

In all, majority had their trips approved by their families. These tallies with the universal aspiration of parents to have their families safe, see their children grow up healthy, strong and educated, and have opportunities for better life [28] both for the children and the parents themselves.

Notwithstanding the difficulties experienced by most who had attempted travelling out, Nigerians still migrate in droves. In 2016 alone, the European border protection agency (Frontex) registered the illegal entry of around 40,000 Nigerians, almost double the number recorded in 2015. Nigerians have been referred to as the third largest group to enter Europe without valid documents, after the Syrians and Afghans and in 2016, over 6,000 Nigerians were refused permits to stay in the European Union (EU), while over 1,500 were forcibly repatriated [29]. Who 


\section{Psychology \& Psychological Research International Journal}

knows how many of these illegal or repatriated Nigerians came down with mental illnesses?

\section{Conclusion}

Migration has strong association with increased risk of developing or precipitating mental disorders. Various factors interact to aid the development of mental disorders in emigrants. Discrimination, disappointment on realization of a great discrepancy between premigratory expectations and reality on ground, accommodation, financial and language challenges, and exposure to various other stresses all impact on the psych and make vulnerable individuals break down.

\section{Recommendations}

Young people should be encouraged to travel out of Nigeria for independent life only when they are matured enough and have adequate social/economic support. Parents should be discouraged from compelling their children to study a particular course even when it is obvious that the child is not willing or academically fit to go into such a discipline. Parents should put into consideration the opinions of their children while choosing a university degree or the type of trade or business the child should embark on. Those that are vulnerable (such as those with family or past history of mental disorders) should be evaluated properly and certified stable enough to travel before leaving the country. Most importantly, those with previous history of mental disorders should be advised to register in a Mental Health facility immediately they reach the new country and not to wait till they break down before seeking health care. Nigerian government should strive harder to address the factors necessitating her citizens to migrate out of the country. Further studies that will compare the profiles of Nigerian emigrants with consequent mental disorders with that of emigrants who developed no mental problem though equally exposed to the same conditions are encouraged.

\section{References}

1. Bhugra D (2004) Migration, distress and cultural identity. British Medical Bulletin 69(1): 129-141.

2. Özgur EM, Deniz A (2014) A migration system formation based on tourism between Russia and Turkey (Antalya) Aegean Geographical Journal 23(2): 1-18.
3. Simich L (2009) Health literacy, immigrants, and mental health. Public Health Agency of Canada and in Contact, The journal of TESL Ontario.

4. Ödegaard O (1932) Emigration and insanity. Acta Psychiatr Neurol Suppl 4.

5. Bhugra D (2000) Migration and schizophrenia. Acta Psychiatr Scand Suppl 107(407): 68-73.

6. Cochrane R, Bal SS (1987) Migration and schizophrenia: an examination of five hypotheses. Soc Psychiatry 22: 180 -191.

7. Sarihasan I (2013) The gender differences of immigration in OECD countries. PhD work, University of Debrecen.

8. International Organization for Migration, IOM (2018) Gender and migration: World migration report, 2018.

9. Kessler RC, Amminger GP, Aguilar-Gaxiola S, Alonso J, Lee S, et al. (2007) Age of onset of mental disorders: A review of recent literature. Curr Opin Psychiatry 20(4): 359-364.

10. Darkwah SA, Verter N (2014) Determinants of international migration: The Nigerian experience. Acta Universitatis Agriculturae ET Silviculturae Mendelianae Brunensis 62(2): 321-327.

11. Komolafe J (2008) Nigerian migration to Ireland: movements, motivations and experiences. Irish Geography 41(2): 225-241.

12. Isiugo-Abanihe UC (2016) Migration in Nigeria: A country profile 2014. International Organization for Migration, Pp: 136.

13. Agrawal S, Taylor FC, Moser K, Narayanan G, Kinra S, et al. (2015) Associations between sociodemographic characteristics, pre-migratory and migratory factors and psychological distress just after migration and after resettlement: The Indian migration study. Indian J Soc Psychiatry 31(1): 55-66.

14. University Application Advice for Nigerian Students (2018).

15. Trip Advisor (2018) Nigeria: Crossing the Border. 


\section{Psychology \& Psychological Research International Journal}

16. Metcalfe-Hough V (2015) The migration crisis? Facts, challenges and possible solutions. Overseas Development Institute 1-6.

17. Mbah M (2015) Highly-skilled Nigerian migration as a spatial and temporal continuum. Sussex Centre for Migration Research University of Sussex. Working Paper No. 80.

18. Carta MG, Bernal M, Hardoy MC, Haro-Abad JM (2005) Migration and mental health in Europe (the state of the mental health in Europe working group: appendix 1). Clinical Practice and Epidemiology in Mental Health 1:13.

19. Wolf S, Hahn E, Dettling M, Nguyen M, Wingenfeld K, et al. (2017) Migration-related stressors and their effect on the severity level and symptom pattern of depression among Vietnamese in Germany. Depression Research and Treatment 2017: 9.

20. Tayo AO (2017) Brain Drain: How Nigerians get to overseas illegally. Africa Telescope Magazine Nov 2017.

21. Scholz J (2017) Nigeria moves to stop illegal emigration. DW Communications.
22. Najjair H (2018) 252 Nigerian illegal immigrants repatriated to their home country. The Libyan Observer.

23. Nuñez C (2014) The 7 biggest challenges facing refugees and immigrants in the US. Citizenship.

24. Abbott A (2016) The mental-health crisis among migrants. Nature 538(7624): 158-160.

25. Cantor-Graae E, Selten JP (2005) Schizophrenia and migration: a meta-analysis and review. Am J Psychiatry 162(2): 12-24.

26. Haasen C, Yagdiran O, Mass R, Krausz M (2001) Schizophrenic disorders among Turkish migrants in Germany. A controlled clinical study. Psychopathology 34(4): 203-208.

27. Bhugra D, Jones P (2001) Migration and mental illness. Advances in Psychiatric Treatment 7(3): 216222.

28. UNICEF (2015) In search of Opportunities-Voices of children on the move in West and Central Africa.

29. Nigerian would-be migrants tell of ordeal on return home. 